\title{
Implementation of Somatic, Auditory, Visual and Intellectual (SAVI) Approaches to Improve Student's Mathematics Communication Skills in SMK Negeri 1 Nisam
}

\author{
Muhammad Ichsan Abda1,a, Muliana $a^{1, b}$, and Mutia Fonna ${ }^{1, c^{*}}$ \\ ${ }^{1}$ Department of Mathematics Education, Malikussaleh University, Aceh Utara, Indonesia \\ a ichsanabda2904.mia@gmail.com; b muliana.mpd@unimal.ac.id; c mutia.fonna@unimal.ac.id \\ *Corresponding Author: mutia.fonna@unimal.ac.id
}

How to Cite : Abda, M.,I., Muliana, M., Fonna, M. (2020). Implementation of Somatic, Auditory, Visual and Intellectual (SAVI) Approaches to Improve Student's Mathematics Communication Skills in SMK Negeri 1 Nisam. International Journal for Educational and Vocational Studies, 2 (6), 422-428. DOI: https://doi.org/10.29103/ijevs.v2i6.2729

\section{ARTICLE HISTORY}

Received: 22 October 2019

Revised: 24 January 2020

Accepted: 18 May 2020

\section{KEYWORDS}

Mathematical Critical Thinking; Mathematical Communication Skills; Somatic, Auditory, Visual, and Intellectual Approaches (SAVI)

\begin{abstract}
The purpose of writing this paper is to study the enhancement of mathematical communication skills of students who have gained the implementation of Somatic, Auditory, Visual, and Intellectual (SAVI) approaches better than those who have learned scientific approaches. The approach used is a quantitative approach with the type of quasi-experimental design with a nonequivalent control group design. The population in this study are all grade $X$ students of SMK Negeri 1 Nisam with a sample of TBSM II class students as an experimental class and TKJ I as a control class taken to use the purposive sampling technique. The data collection techniques used in this research are mathematical communication skills tests of students and observation sheets. Data analysis was done using test-t, that because the data of the n-gain score obtained with normal distribution, but has a variance that is not homogeneous. The significant result of the statistics equal variances not assumed is 0.00 smaller than $0.05 \mathrm{HO}$ is rejected. The result showed that the enhancement of mathematical communication skills of students who gained the implementation of somatic, auditory, visual, and intellectual (SAVI) were better than students who gained scientific learning approaches.
\end{abstract}

\section{INTRODUCTION}

Mathematics is a field of science that has an important role in aspects of life. In accordance with Siagian's (2016: 58) statement of the importance of mathematics in life because it will have a clearer and more directed view and direction of life, therefore good education is education that not only prepares students for a profession but how education can prepare participants students to be able to communicate the problems that will be encountered in everyday life such as for buying and selling in the market, calculating the distance and speed of the vehicle. Learning mathematics is expected to be able to make students who have the ability to communicate actively, think creatively, reason, and have useful basic knowledge and skills.

The purpose of learning mathematics has several components, according to the Ministry of Education and Culture of the Republic of Indonesia (Kemendikbud, 2013) that the purpose of learning mathematics in applying the 2013 curriculum is that students are able to improve intellectual abilities, shape students' abilities in solving problems systematically, obtain high learning outcomes, train students in communicating ideas, especially in writing works, develop student character. Mathematics learning objectives formulated by the National Council Teachers of Mathematics NCTM (2000: 29), namely, learning to communicate (mathematical communication), learning to the reason (mathematical reasoning), learning to solve problems (mathematical problem solving), learning to link ideas (mathematical connections), the formation of positive attitudes towards mathematics (positive attitudes toward mathematics). Hendriana (2016: 29) suggests that the learning component of mathematics is to be able to communicate ideas with symbols, tables, diagrams, or mathematical expressions to clarify the situation or problem, and have an attitude of appreciating the usefulness of mathematics in everyday life, an attitude of curiosity, attention, and interest in studying mathematics.

To achieve the goal of learning mathematics the teacher must be creative because the changes required in its implementation require appropriate planning and 
consideration. The teacher must be able to invite students to communicate in learning activities, so those abstract mathematics can be conveyed in real problems in life and students are able to communicate it. Mathematical communication skills are abilities that must be possessed by students to achieve learning goals. Related to mathematical communication skills. According to Ansari (2016: 15) communication in mathematics is related to the abilities and skills of students in expressing mathematical ideas consisting of, verbal communication (talking) and written communication (writing).

The low mathematical communication skills of students are seen in the results of Hima's research (2015: 120) which shows that students' mathematical communication abilities are still low both verbally and in writing. Furthermore, Ansari (2016: 3) said that students' low mathematical communication skills were caused by teachers in teaching often exemplifying students how to solve problems, students learning by listening and watching teachers solve math problems, and when teaching mathematics the teacher immediately explained the material learned.

The results of observations made by researchers at SMK Negeri 1 Nisam on March 5-6 2019 concluded that the learning developed by teachers so far has not supported the development of students' mathematical communication skills, there are still many complaints from students about the low ability of students in mathematics applications in life, learning is one-way and students are not actively involved in exploring mathematical concepts or ideas in a deep and meaningful way so that students receive knowledge in a ready-made form, it is more rote in nature and makes students dislike learning mathematics. Coupled with the admission of students who have a lot of difficulty in solving math problems in the form of concepts, formulas, and difficulties in mathematical communication. He continued, students had difficulty with trigonometric triangle formulas to communicate. In dealing with these difficulties, students need practice, guidance to learn to combine skills and analyze the main problems that cause students to experience difficulties in calculating using trigonometric formulas so that students' difficulties in mathematical communication can be overcome.

This is clearly very bad for the development of mathematics education in the future. Therefore, changing a fun mathematics learning approach should be a top priority. Mathematics learning is not only related to learning concepts, procedures, and applications but is also related to developing an interest and interest in mathematics as a powerful way to solve math problems (Putranti and Prahmana, 2018: 3). In this case, the Somatic, Auditory, Visual, and Intellectual (SAVI) approach is a form of approach that is thought to be able to collaborate with mathematical communication skills and can enhance these abilities.
Somatic, Auditory, Visual, and Intellectual (SAVI) learning approach is a learning approach to understand, explain, and communicate mathematical concepts which have Somatic learning elements (learning by moving and doing), Auditory learning (learning by speaking and listening ), Visual learning (learning by observing and describing), Intellectual learning (learning by solving problems and pondering). According to Meier (2005: 100), learning will be optimal if the elements in SAVI are in the teaching and learning process. Based on the background of the problems described above, the formulation of the problem for this study is whether the increase in mathematical communication skills of students who apply the Somatic, Auditory, Visual, and Intellectual (SAVI) approach is better than students who get the scientific learning approach?.

\section{LITERATURE REVIEW}

Communication in English communication comes from the Latin word communication and comes from a word that means the same. Then communication will occur as long as there is a similarity in meaning about what is being discussed. Within (in Herdian, 2010: 10) suggests that communication skills are important when discussions between students are held, where students are expected to be able to state, explain, describe, listen, ask and work together so that they can lead students to a deep understanding of mathematics. So, mathematical communication skills are students' abilities in terms of explaining ideas, situations, relations, and everyday events into a mathematical model using their own words.

Communication skills are needed in the teaching and learning process because good communication will invite students to be active in the teaching and learning process and make it easier for them to provide reasoning for this information. To convey mathematical ideas so that they can be well received, communication is needed that can give students the opportunity to hear and speak (Auditory), listen (Visual), use their reasoning (Intellectual), and the final result can be actualized through presentations (Somatic) in full confidence and have a positive attitude towards mathematics (Mathematical Disposition).

To develop communication skills, students can be guided in communicating in various languages including mathematical languages. According to Barrody (in Simamora, 2017: 60) states that mathematics communication needs to be developed among students for two reasons, namely: First, mathematics as language; it means that mathematics is not just a tool for thinking, a tool for finding patterns, solving, but mathematics is also a tool for communicating ideas clearly, precisely and accurately. Second, mathematics learning as a social activity; meaning as a social activity in learning mathematics, mathematics is also a vehicle for social interaction, as well as communication between teachers and students. Indicators of mathematical communication 
skills in this study are limited to 4 indicators, namely (1) declaring daily events into a mathematical model, (2) stating a mathematical model in the form of images using one's own words, (3) explaining ideas, situations, and mathematical relations, and (4) explain the complete procedure.

Somatic, Auditory, Visual, and Intellectual (SAVI) approach is an approach to understanding, explaining, and communicating mathematical concepts which have the following learning factors, somatic/learning by moving and doing (learning by moving and doing), auditory/learning by talking and bearing (learning by speaking and listening), Visual/learning by observing and picturing (learning by observing and describing), and Intellectual/learning by problem-solving and reflecting (learning by problem-solving and reflecting).

The scientific approach is a scientific framework of learning that is carried by the 2013 curriculum. The steps in the scientific approach are a form of adaptation of scientific steps in science. The learning process can be integrated with a scientific process, therefore the 2013 curriculum mandates the essence of a scientific approach in learning. According to Sariningsih (2016: 3), scientific learning is learning that adopts scientific steps in building knowledge through scientific methods.

\section{METHODS}

The approach used in this research is a quantitative research approach. This type of research used in this research is quasi-experimental design (quasiexperimental) with data analysis techniques processed from data obtained from the research results in the form of numbers and analyzed using statistical formulas. This research was conducted at SMK Negeri 1 Nisam in class X in North Aceh Regency. For that, it is necessary to use a sampling technique. Researchers used a purposive sampling technique, namely the technique of determining the sample using consideration. Researchers treated the experimental class with the Somatic, Auditory, Visual, and Intellectual (SAVI) approach which was carried out in the even semester of the 2018/2019 academic year. Meanwhile, the control class uses a scientific approach. The design used is the nonequivalent control group design, as suggested by Sugiyono (2016: 79), as follows:

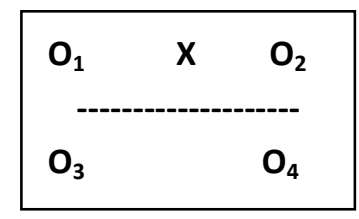

\section{Information:}

O1 : Pretest for the Experiment class

O2 : Posttest for the Experiment class

$\mathrm{X}$ :Application of Somatic, Auditory, Visual, and Intellectual (SAVI) approaches

O3 : Pretest for the Control class

\section{O4: Posttest for the Control class}

The data collected in this study included all activities from start to finish which was taken through several techniques, namely tests and observations. The data analysis technique in this study was carried out by testing the statistical requirements needed as a basis for hypothesis testing, including data normality test, variance homogeneity test, and t-test. All statistical calculations use the help of the SPSS 18 computer program and Microsoft Office Excel 2007.

\section{RESULTS AND DISCUSSION}

\subsection{Results}

Mathematical communication ability test results provide information about students' abilities before and after the learning process, both in the experimental class and in the control class. Data is presented in the following figure:

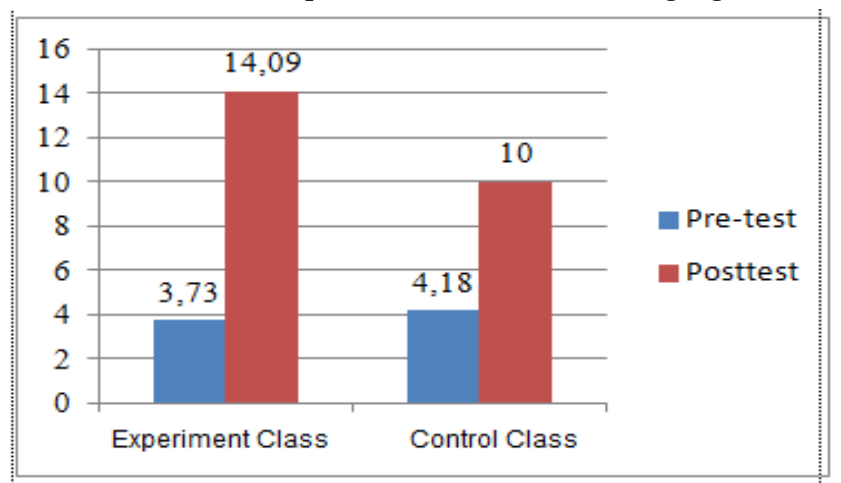

Figure 1. Diagram of Pre-test and Posttest Average Communication Skills

In the diagram above, it can be seen that the pre-test mean score of students' mathematical communication skills for the experimental class with a score of 3.73 is lower than the pre-test mean for the control class with a score of 4.18. While the average posttest score of students after the learning process for the experimental class with a posttest score of 14.09 was higher than the control class with a posttest score of 10 . To see an increase in mathematical communication skills between students who received learning approaches to Somatic, Auditory, Visual, and Intellectual (SAVI) with students who have learned a scientific approach by calculating the $\mathrm{N}$-gain of both classes. The average N-Gain can be seen in Figure 2 .

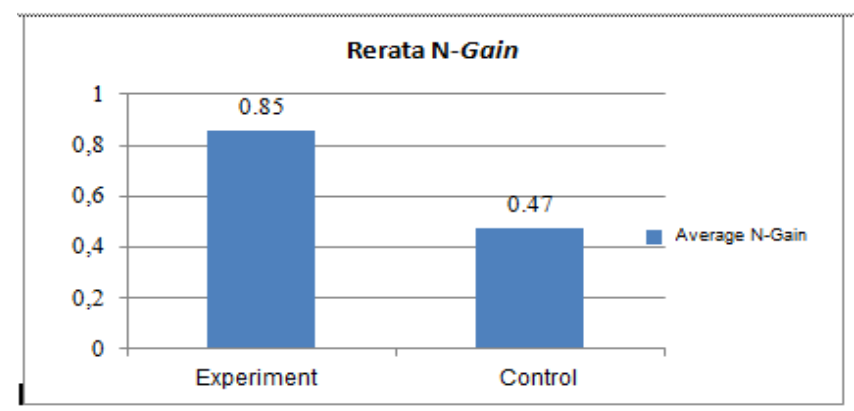

Figure 2. Diagram of Average N-Gain Mathematical Communication Ability 
In figure 2 above it can be seen that the average $\mathrm{N}$-Gain mathematical communication skills in the experimental class with a score of 0.85 looks higher than the average $\mathrm{N}$-Gain mathematical communication skills in in the control class with a score of 0.47 . From the results of of N-Gain, it shows that the ability of mathematical communication with the application of the Somatic,
Auditory, Visual, and Intellectual (SAVI) approach is higher than the mathematical communication ability by applying the scientific approach.

The normality test in this study used the Kolmogorov-Smirnov test. The normality test results are as follows:

Table 1. Tests of Normality

\begin{tabular}{ccccccccc}
\hline & \multirow{2}{*}{ Group } & \multicolumn{3}{c}{ Kolmogorov-Smirnova $^{2}$} & \multicolumn{3}{c}{ Shapiro-Wilk } \\
\cline { 3 - 8 } N-Gain & Statistic & df & Sig. & Statistic & df & Sig. \\
\cline { 2 - 8 } & Experimen & .149 & 22 & $.200^{*}$ & .904 & 22 & .036 \\
\hline & Control & .120 & 22 & $.200^{*}$ & .933 & 22 & .139 \\
\hline
\end{tabular}

Based on Table 1 above, the significance value of the Kolmogorov-Smirnov test on the N-Gain score of the experimental class and control class mathematical communication ability is 0.200 because 0.200 is greater than 0.05 , both the experimental class and the control class can be concluded that the N-Gain score is the mathematical communication ability. students are normally distributed. For more details, see figures 3 and 4 .

4.

Normal Q-Q Plot of NGain

for KELOMPOK= Eksperimen

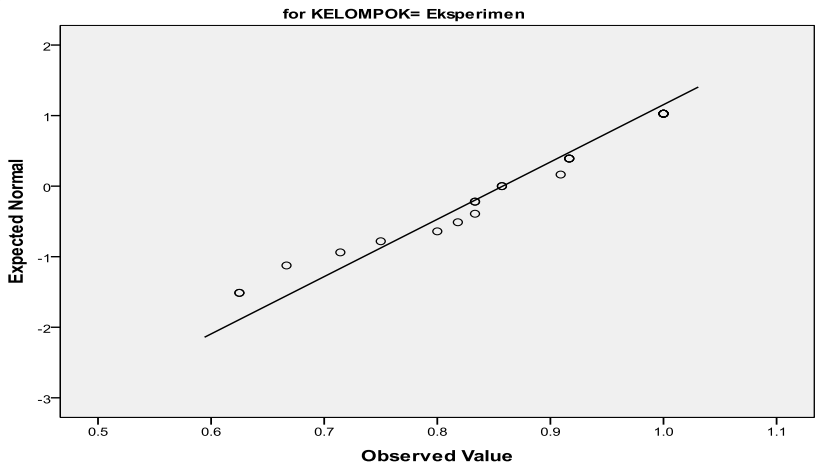

Figure 3. N-Gain Normality Test Results for Experiment Class

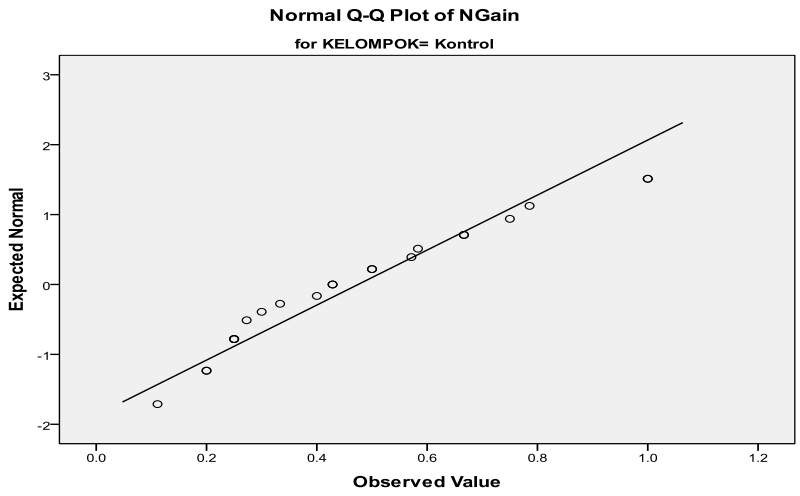

Figure 4. Control Class N-Gain Normality Test Results

The variance homogeneity test for increasing communication skills in this study used the Levene Statistic test. The following is a summary of the homogeneity test for increasing mathematical communication skills:
Table 2. Test of Homogeneity of Variances

N-Gain

\begin{tabular}{cccc}
\hline Levene Statistic & df1 & df2 & Sig. \\
\hline 10.440 & 1 & 42 & .002 \\
\hline
\end{tabular}

Based on Table 2, the significance value of mathematical communication skills is 0.002 because 0.002 is less than 0.05 , it can be concluded that the variance of the N-Gain score of mathematical communication ability has a non-homogeneous variance.

Hypothesis testing in this study uses the t-test technique because the results of the test for normality and homogeneity of data variance show that the data on students' mathematical communication skills is normally distributed and has a variance that is not homogeneous. The following is a summary of the results of the $t$ test 'mathematical communication skills, as follows:

Based on the data in the table above, the results of calculations using t-test analysis for data on students' mathematical communication skills were obtained 0.00 . According to the test criteria, if the value in the column is sig. $<0.05$ then $\mathrm{HO}$ is rejected. From the significant results of the equal variances not assumed statistic, it is 0.00 less than 0.05. Then $\mathrm{HO}$ is rejected. The testing is based on a hypothesis

$H_{0}: \mu_{1}=\mu_{2} \quad$ : The improvement of students' mathematical communication skills who obtained the Somatic, Auditory, Visual, and Intellectual (SAVI) approach was the same as the mathematical communication skills of students who obtained a scientific approach.

$H_{a}: \mu_{1}>\mu_{2} \quad$ : The improvement of students' mathematical communication skills who received the Somatic, Auditory, Visual, and Intellectual (SAVI) approach was better than the mathematical communication skills of students who received a scientific approach. 
Table 3. Independent Samples Test

\begin{tabular}{|c|c|c|c|c|c|c|c|c|c|c|}
\hline & & \multicolumn{5}{|c|}{$\begin{array}{c}\text { Levene's Test for } \\
\text { Equality of } \\
\text { Variances } \\
\end{array}$} & \multicolumn{2}{|c|}{ t-test for Equality of Means } & & \\
\hline & & & & & & \multirow{2}{*}{$\begin{array}{c}\text { Sig. } \\
\text { (2-tailed) }\end{array}$} & \multirow{2}{*}{$\begin{array}{c}\text { Mean } \\
\text { Difference } \\
\end{array}$} & \multirow{2}{*}{$\begin{array}{l}\text { Std. Error } \\
\text { Difference }\end{array}$} & \multicolumn{2}{|c|}{$\begin{array}{c}95 \% \text { Confidence Interval of } \\
\text { the Difference }\end{array}$} \\
\hline & & $\mathrm{F}$ & Sig. & $\mathrm{t}$ & df & & & & Lower & Upper \\
\hline \multirow[t]{2}{*}{ NGain } & Equal variances assumed & 10.440 & .002 & 6.361 & 42 & .000 & .38293 & .06020 & .26143 & .50442 \\
\hline & $\begin{array}{l}\text { Equal variances not } \\
\text { assumed }\end{array}$ & & & 6.361 & $\begin{array}{c}30.34 \\
0\end{array}$ & .000 & .38293 & .06020 & .26003 & .50582 \\
\hline
\end{tabular}

It can be concluded that the improvement of students' mathematical communication skills who received the Somatic, Auditory, Visual, and Intellectual (SAVI) approach was better than the mathematical communication skills of students who received a scientific approach.

The results of observations of teacher and student activities during the learning process were stated in the assessment category, namely the scores (1) very poor, (2) less, (3) sufficient, (4) good, and (5) very good. These observations were made to direct learning activities in accordance with the research objectives and to determine the feasibility of learning mathematics in accordance with the stages with the Somatic, Auditory, Visual, and Intellectual (SAVI) approach. The observation sheet was filled in by the observer, namely the teacher in the field of mathematics studies at SMK Negeri 1 Nisam, so the activities carried out by students with the application of the Somatic, Auditory, Visual, and Intellectual (SAVI) approach were classified as very good with a percentage of $84.55 \%$. His achievement has increased from the 1st meeting to the 4 th meeting which shows that during the learning process students begin to get used to learning with the application of the Somatic, Auditory, Visual, and Intellectual (SAVI) approach which at first feels new to them.

\subsection{Discussion}

In this study, the researcher acted as the executor of the Somatic, Auditory, Visual, and Intellectual (SAVI) approach to learning experiments. In general, the implementation of all components in the Somatic, Auditory, Visual, and Intellectual (SAVI) approach is going well. The first component is the preparatory or preliminary stage, the teacher tries to arouse student interest, gives positive feelings about future learning experiences, and puts them in optimal situations for learning, while students pay close attention and respond positively. At first, many students were still confused. This is due to their habits in scientific learning, where the teacher explains the main points in the learning material, and then complete the students find out from various sources so that it overwhelms students. Even though students have been given an explanation that in learning the Somatic, Auditory, Visual, and Intellectual (SAVI) approach, students still want to be treated as in scientific learning. At first, it is still difficult to generate motivation, interest, and curiosity from students. But at the next meeting students continue to learn to keep giving positive feelings towards their interest in learning mathematics so as to create useful learning. In the preliminary stage, students hear what is conveyed and summarize it themselves, meaning students have learned by involving the ability to hear or auditory learning styles to keep giving positive feelings to the interests of learning mathematics.

In the second component, the delivery phase, the teacher helps students find new learning material in a way that is unique, interesting, fun, involves the five senses, and is suitable for all learning styles. In this activity, the teacher explains the material briefly, while students pay close attention and find new things that make themselves fun in learning. Each student actively understands LAS with their own learning style. Furthermore, students exchange opinions and communicate with other students based on LAS and their own learning styles. In this delivery stage, the teacher's job is to act as a facilitator and guide students to build and shape their knowledge through learning styles that students enjoy. Occasionally students who still don't understand ask the teacher because none of them understand and the teacher explains in a direction so students find their own answers. At the stage of delivery of the material the teacher describes the process, principles, or meanings that are imitated to students directly, meaning that students have involved visual abilities or visual learning styles to observe that make themselves enjoyable in learning. During the learning process, the teacher goes around while observing each student if there are difficulties in learning and giving encouragement and applause from every little thing done or from a good answer. At first, there were still many students who were shy about motivating each other. This is due to their habits in scientific learning, where the teacher explains the material without giving little support to students.

The third component, namely the training stage, the teacher helps students integrate, absorb new knowledge and skills in various ways. At this stage, every student tries to be active and really practice in learning so that it shows the real thing. In addition, student processing 
activities in solving problems in LAS then communicate with other students by providing support to each other. The main thing in this training stage is teaching again, meaning that students who want to volunteer to come to the front of the class in answering the questions on the blackboard, then explain back to their classmates in the training process to communicate. The existence of this movement also supports learning styles between students, making them more eager to learn and more exciting in learning, especially in accordance with the characteristics of their own learning styles. At the training stage, students show what they have done internally in their minds. When they use intelligence, it means that students have used their thinking skills or intellectual learning style to solve the problems on the student activity sheet.

The fourth component, namely the performance stage of results, the teacher helps students apply and expand their new knowledge or skills on the job so that communication skills will stick and the appearance of the results will continue to improve. At this stage, the application of learning to the real world in immediate time, for example in the material that the researcher is testing is trigonometry, in determining the angle the teacher asks students to apply the concept of determining the angle between the arm and the elbow. At the special angle stage, the teacher asks students to strengthen their memory by matching codes on the fingers. This is done, with consideration of sufficient time to do what will later be combined to facilitate further learning. In the results display stage, after students display the results of the lesson, then the teacher guides students who are still having difficulty in the performance stage. Students continue to actively ask questions, create active learning training for all students and get up from their seats to create results in a process, meaning that students have physically involved and moved it during teaching and learning or somatic learning styles to make movements.

Mathematical communication skills are the ability of students to use mathematics as a communication tool and the ability to communicate the mathematics they have learned. The aspects that are measured are stating everyday events into a mathematical model, stating a mathematical model of a picture using one's own words, explaining mathematical ideas, situations and relations, and explaining settlement procedures. The average posttest score of the mathematical communication ability of the experimental class students was 14.09 while the average posttest score in the control class was 10 . There was a significant difference between the average posttest score of the mathematical communication ability of the experimental class students and the control class. The results of the posttest average experimental class per question indicator are as follows:

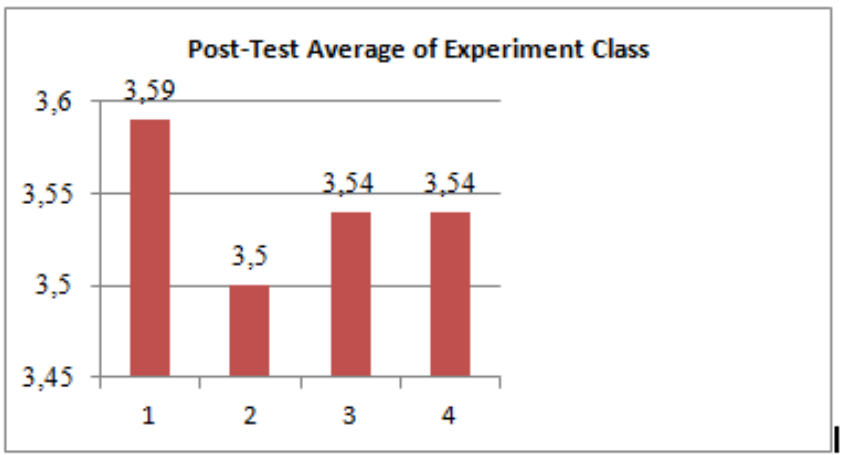

Figure 5. Average Post-Test Values Per-Indicator Questions in Experimental Classes

In Figure 5 above, the average value for question number 1 represents the first aspect indicator, namely expressing everyday events into a mathematical model with an average score of 3.59. At first, students still find it difficult to state everyday events in trigonometric models about angles, after the teacher directs one example, then students can give examples of everyday events to be modeled in mathematics and able to state it in more detail in the learning process, such as angles formed by the hours and angles formed by the elbows of students' hands, also supported by student activity sheet 1 which invites students to work on several questions related to the first aspect indicator. The average value for question number 2 represents the second aspect indicator, namely stating the mathematical model of the image using your own words with a score of 3.5. The teacher tries to convey the material until students understand what has been explained, then restates using their own words, only a few students can explain again, after being repeated the second time, many students scramble to explain in front of the class so that the student's ability continues to increase From one student's explanation to another there is a difference in delivery so that students continue to play a role in communicating in learning and are supported by student activity sheets 2 .

The average score for question number 3 represents the third aspect indicator, namely explaining mathematical ideas, situations, and relations with a score of 3.54. In learning, the teacher facilitates students to expand their knowledge, guide students who are still having difficulties, and explain some new relationships and ideas in learning mathematics. Many students can explain mathematical ideas, situations, and relations because they are accustomed to conveying in their own words, some other students can to find relationships-but are still shy in explaining their ideas so that student activity sheet 3 helps students explain in writing to master the third indicator this. The average value for question number 4 represents the last aspect indicator measured is explaining the complete procedure with a score of 3.54. Supporting the result display stage to explain the procedure for solving practice questions in front of the class and supporting the smooth communication between students so that communication skills will continue to improve, students ask each other to 
strengthen the material that has been explained.

Based on the results of the data analysis of students' mathematical communication skills, it was obtained that the class using the Somatic, Auditory, Visual, and Intellectual (SAVI) approach was better than those using the scientific approach. The findings in this study are supported by Maharani (2016) which states that the improvement of students' mathematical communication skills using the Somatic, Auditory, Visual, Intellectual (SAVI) learning approach is better than students who use ordinary learning models. Besides, research conducted by Fahradina, et al. (2014) stated that the increase in mathematical communication skills of students who received learning with the group investigation model was better than the mathematical communication skills of students who received conventional learning based on student level.

\section{CONCLUSION}

Based on the results of data analysis and discussion, it was concluded that the increase in mathematical communication skills of students who applied the Somatic, Auditory, Visual, and Intellectual (SAVI) approach was better than students who received the scientific learning approach.

The suggestion that the researchers put forward from the results of this study is that learning mathematics using the Somatic, Auditory, Visual, and Intellectual (SAVI) approach can be expanded its use, not only in trigonometry material but also in other mathematics subject matter. For further research, this research should be complemented by researching other aspects of mathematical abilities, namely: the ability to understand, reason, connect, and represent in more detail and be able to research the school level that is not currently reached by researchers, so that make learning mathematics more fun for life.

\section{REFERENCES}

Ansari, B.I. (2016). Komunikasi Matematik Strategi Berpikir dan Manajemen Belajar. Banda Aceh: PeNa.

Fahradina, N., Ansari, B.I., dan Saiman. (2014). "Peningkatan Kemampuan Komunikasi Matematis dan Kemandirian Belajar Siswa SMP dengan Menggunakan Model Investigasi Kelompok”. Jurnal Didaktik Matematika. 1(1): 54-64.

Herdian. (2010). "Kemampuan Komunikasi Matematis". diakses pada 20 Februari 2019.

Hendriana, H., dan Utari Sumarmo. (2016). Penilaian Pembelajaran Matematika. Bandung: PT. Refika Aditama.

Hima, L.R. (2015). "Penerapan Model Pembelajaran Problem Based Learning Ditinjau Dari Kemampuan
Komunikasi Matematik". Jurnal Ilmiah Pendidikan Matematika 4 (2): 111-121.

Kementrian Pendidikan dan Kebudayaan. (2013). Struktur dan isi kurikulum 2013. Jakarta: Kemendikbud.

Maharani, S. (2016). "Pengaruh Pendekatakan Pembelajaran SAVI terhadap Peningkatan Kemampuan Komunikasi Matematis Siswa SMP”. Skripsi. Bandung: Universitas Pasundan.

Maharani, A. (2018). "Menumbuhkan Kemampuan Disposisi Matematis Melalui Model PBL dengan Metode Team Teaching”. JNPM (Jurnal Nasional Pendidikan Matematika), 2(2): 197-205.

Meier, D. (2000). The Accelarated learning handbook. Panduan Kreatif \& Efektik Merancang Program Pendidikan dan Pelatihan. Terjemahan oleh Rahmani Astuti. 2005. Bandung: KAIFA.

National Council Teachers of Mathematics. (2000). Principles and Standards for School Mathematics. USA: NCTM.

Siagian, M.D. (2016). "Kemampuan Koneksi Matematik Dalam Pembelajaran Matematika". Jurnal MES, 2(1): 58-67.

Sariningsih, R., dan Kadarisma, G. (2016). "Meningkatkan Kemampuan Berpikir Kreatif Matematis dan Kemandirian Belajar Siswa SMP melalui Pendekatan Saintifik berbasis Etnomatematika". Jurnal P2M STKIP Siliwangi, 3(1): 53-56.

Simamora, R. (2017). "Implementasi Kurikulum 2013 terhadap Kemampuan Komunikasi Matematika Siswa pada Materi Program Linear di kelas XI SMA Negeri 2 Pematang Siantar". Jurnal MES. 2(2): 59-69.

Sugiyono. (2016). Metode Penelitian Kuantitatif, Kualitatif, dan $R \& D$. Bandung: Alfabeta.

Putanti, S.D., dan Prahmana, R.C.I. (2018). "Kemampuan Siswa Dalam Menyelesaikan Soal Matematika Berbasis Masalah”. Jurnal JNPM, 2(1): 86-97. 